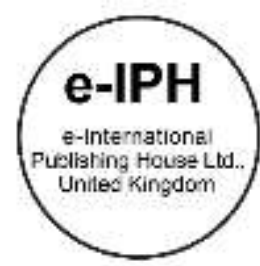

\title{
Enhancement for Rural Livability: Changes and impacts on the traditional Malay settlement
}

\author{
Nor Zalina Harun, Najiha Jaffar \\ Institute of Malay World and Civilization, \\ The National University of Malaysia, Bangi 43600, Selangor, Malaysia \\ najihajaffar13@gmail.com,nzalina@ukm.edu.my \\ $+60192490357$
}

\begin{abstract}
A traditional settlement is defined as an area with sound and a strong sense of traditional village character inhabited by a society that preserves their cultural and traditional practices. However, the society's traditions and way of life have continuously been threatened as the country moves towards urbanisation, which is gradually changing the settlements. The objectives of this research are to identify the changes in the traditional settlement and identify the issues in deterioration of traditional Malay settlement. A mixed-method approach applied as the research methodology. The findings revea the changes and impact include six underlying factors; natural disaster, lack of maintenance, modern development, destruction by irresponsible parties, lack of awareness and declining of traditional product in the market.
\end{abstract}

Keywords: traditional settlements; issues; heritage sites; preservation of heritage sites

eISSN: 2398-4287 @ 2018. The Authors. Published for AMER ABRA cE-Bs by e-International Publishing House, Ltd., UK. This is an open access article under the CC BYNC-ND license (http://creativecommons.org/licenses/by-nc-nd/4.0/). Peer-review under responsibility of AMER (Association of Malaysian Environment-Behaviour Researchers), ABRA (Association of Behavioural Researchers on Asians) and CE-Bs (Centre for Environment-Behaviour Studies), Faculty of Architecture, Planning \& Surveying, Universiti Teknologi MARA, Malaysia.

https://doi.org/10.21834/e-bpj.v3i9.1544

\subsection{Introduction}

Settlement acts a significant role in creating human civilisation by presenting space to satisfy the inhabitants both in the present-day and the future time. The traditional settlement generally represents a unique combination of natural, cultural, and urban and sub-urban social features (Nguyen, H. M., 2013). However, the passage of time followed by the tide of modernisation and development, directly and indirectly, have changed the local identity and way of life. The growth of new towns in a country has eroded the cultural and physical landscapes especially of traditional Malay settlements (Ariffin, 2007). Rapid urbanisation is the most factor of changes and threats to the heritage preservation of the traditional Malay settlement. Urbanization always refers to intensive processes of alteration from rural to urban which involves population, land use and development, economic and culture (McGranahan, G., \& Satterthwaite, D, 2014). Based on the articles by Abd Razak (2015), it has identified that the village or hometown was vanishing due to modern development. The impact of the destruction of village setting has decreased the function of landscape physical in the traditional settlement. Such change has led to the changes in people's interaction with their environmental setting. Therefore, people will less in appreciating and aware of their culture. The disappearance of the village is the disappearance of local languages and traditions, consequently, robs the richness of Malaysia's diversity, cultural balance, and living heritage. Besides, the values of the traditional settlement have been neglected from the community perspectives as they only preferred to preserve the architectural buildings heritage rather than the site surrounding. Thus, this paper aims to identify the current changes and impacts concerning on the preservation of the traditional Malay settlement to find the possible approaches in sustaining the rural liveability by dealing with the changes and impacts discovered.

eISSN: 2398-4287 @ 2018. The Authors. Published for AMER ABRA cE-Bs by e-International Publishing House, Ltd., UK. This is an open access article under the CC BYNC-ND license (http://creativecommons.org/licenses/by-nc-nd/4.0/). Peer-review under responsibility of AMER (Association of Malaysian Environment-Behaviour Researchers), ABRA (Association of Behavioural Researchers on Asians) and cE-Bs (Centre for Environment-Behaviour Studies), Faculty of Architecture, Planning \& Surveying, Universiti Teknologi MARA, Malaysia.

https://doi.org/10.21834/e-bpj.v3i9.1544 


\subsection{Literature review}

According to the cultural landscape studies as shown in Table 1, the issues are a focus on the physical landscape aspect where most of the studies show the occurrence of physical attribute erosion at heritage sites due to rapid industrial development, economic development, and urbanisation; that undermines the traditional physical landscape element of an area. The issues led to heritage site loss of identity as stated by Ariffin (2007); Lee Yoke Lai et al. (2013); Ahmad (2013); Jani (2014), and Samsudin (2017). Azizi (2015) in turn finds that the development of a modern city reduces the quality of social relationships in the society and changes the physical pattern of the residential surroundings. Based on the findings of the following studies, the overall negative impact is the loss of sense of place and the sense of belonging to a heritage site.

Table 1: Issues in the study of the cultural landscape

\begin{tabular}{|c|c|c|c|c|c|}
\hline Year & Researcher & Issue & Factor & Effect & \\
\hline 2007 & $\begin{array}{l}\text { Noor Fazamimah Mohd } \\
\text { Ariffin }\end{array}$ & $\begin{array}{l}\text { Changes in the landscape of } \\
\text { historic town in Kuala } \\
\text { Terengganu }\end{array}$ & $\begin{array}{l}\text { Economic development and } \\
\text { urbanisation }\end{array}$ & Loss of sense of place & 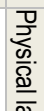 \\
\hline 2013 & $\begin{array}{l}\text { Lee Yoke Lai, Ismail Said, } \\
\text { Aya Kubota }\end{array}$ & $\begin{array}{l}\text { The decline in meaning and } \\
\text { quality of place: field studies in } \\
\text { Kuala Dungun and Taiping }\end{array}$ & $\begin{array}{l}\text { Dramatic changes to replace } \\
\text { traditional buildings and reduce the } \\
\text { value of a place }\end{array}$ & Loss of identity of place & 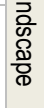 \\
\hline 2013 & Raziah Ahmad & $\begin{array}{l}\text { Changes in cultural landscape in } \\
\text { interior area and erosion of } \\
\text { agricultural area in Peninsular } \\
\text { Malaysia }\end{array}$ & $\begin{array}{l}\text { Economic development and rapid } \\
\text { urbanisation }\end{array}$ & Loss of quality of place & \\
\hline 2014 & $\begin{array}{l}\text { Haza Nurhaza Md Jani, } \\
\text { Mohd Ramzi Mohd } \\
\text { Hussain }\end{array}$ & $\begin{array}{l}\text { Changes in Negeri Sembilan } \\
\text { Minangkabau cultural landscape }\end{array}$ & $\begin{array}{l}\text { Assimilation with other Malay } \\
\text { ethnic groups following migration. } \\
\text { Modern lifestyle and economic } \\
\text { challenges in Negeri Sembilan }\end{array}$ & $\begin{array}{l}\text { Loss of national identity and place } \\
\text { and cultural identity. }\end{array}$ & \\
\hline 2017 & $\begin{array}{l}\text { Noor Aimran Samsudin, } \\
\text { Abdul Razak Jaffar }\end{array}$ & $\begin{array}{l}\text { Demolition and resettlement of } \\
\text { traditional settlement in Kuala } \\
\text { Terengganu coastal area. }\end{array}$ & Rapid urbanisation & $\begin{array}{l}\text { Loss of sense of place and sense of } \\
\text { belonging to a place }\end{array}$ & \\
\hline 2015 & $\begin{array}{l}\text { Hanieh Azizi Ghoomi, } \\
\text { Seyed- Abbas Yazdanfar, } \\
\text { Seyed-Bagher Hosseini, } \\
\text { Saeid Norouzian Maleki }\end{array}$ & $\begin{array}{l}\text { Declining quality of social } \\
\text { relationships: field study in } \\
\text { Tehran }\end{array}$ & $\begin{array}{l}\text { Development of modern city } \\
\text { changes physical pattern of } \\
\text { residential surroundings to modern } \\
\text { pattern. }\end{array}$ & $\begin{array}{l}\text { Loss of spirit and sense of place, the } \\
\text { existence of meaningless place and } \\
\text { the loss of imagination of residence. } \\
\text { Creating individualistic traits. }\end{array}$ & $\begin{array}{l}\text { Oొ } \\
\text { Ф. }\end{array}$ \\
\hline
\end{tabular}

(Source: Author)

Besides, other factors contribute to the deterioration of heritage sites, for example, modern housing schemes with weak cultural values, increasing population, migration, change in lifestyle, and infrastructure development. In a study by Samsudin (2017), he criticises that the traditional Malay way of life and settlements have begun to disappear slowly and replace with western culture-influenced settlement patterns considered more advanced and world-class. In a similar tone, Abd Razak (2015) has identified many traditional settlements in the country that have disappeared due to modern development and the loss of the traditional settlements also represents the loss of local tradition.

Meanwhile, the Berita Harian newspaper (2016) also features 29 traditional settlements located in the north of Peninsular Malaysia that are set to disappear following the threat of development activities by the state's Transport Master Plan projects. Universiti Sains Malaysia (USM) Centre for Policy Research and International Studies (CenPRIS) Director, Associate Professor Dr Azeem Fazwan Ahmad Farouk in a press conference (Berita Harian, 2016) said, the factor that contributes to the loss of the traditional settlements is the issue of ownership of the land inhabited by the villagers. Dr. Azeem Fazwan claimed that when landowners decide to develop their property, villagers are forced to move into modern housing, such as terrace houses and flats, among others.

A study conducted by Shuhana (2011) since 1989 reveals twelve old towns comprising traditional settlements like Kangar, Alor Setar, Taiping, George Town, Kota Bharu, Kuala Terengganu, Kuantan, Melaka, Johor Bahru, Batu Pahat, Kuala Lumpur, and Kuching facing this pressure that causes the loss of identity of the heritage sites. At the global level, rapid development has also erased the character of many heritage sites in Thailand, Singapore, Japan, Korea, and other countries (J. Allister McGregor, 2008; Caroline Ong Shu Xian et al., 2006; Radzuan, 2016). It clearly shows that the problems faced by traditional settlements are increasingly worrying and creating negative impacts regarding social, economic, and the environment when the traditional culture and physical landscape experiences transformation. Therefore, to prevent this scenario from worsening to most other traditional Malay settlements, an approach to assess the physical landscape quality of traditional settlements must become an avenue for raising awareness of the importance of area preservation.

\subsection{Research Methodology}

A mixed-method approach used as the research methodology. The qualitative approach divided into two which are a literature review and observation survey. Library research was conducted to analyse the contents of selected articles comprising journal articles, books, book chapters, urban and rural development planning department reports, newspaper clippings, and web articles from official government portals. The literature review referred to in this study that considered five main keywords namely physical landscape, 
heritage settlement, traditional settlement, heritage, and preservation. The relevance of all keywords is divide into linkage and the importance of physical attributes as well as issues and problems related to the deterioration of traditional Malay settlement. The inventory data collected by the observation survey taken in the sites studies focused on two areas, namely as Seberang Takir Village and Pulau Duyong Village. This traditional Malay settlement was identified and recognised as the settlement that still preserved their physical attributes with a strong identity. Meanwhile, questionnaire surveys took the quantitative approach. This research identifies the factors of impacts of changes in the traditional Malay settlement. This research employs 220 respondents of local people around 21-60 years old. The questionnaire survey is distributed to the nodes of people place in the traditional Malay settlement territory. The questionnaire survey comprised of four sections with multiple choice question by Likert scale and open-ended questions.

\subsection{Site Studies}

The site is located at Seberang Takir Village and Pulau Duyong Village. It is situated in the district of Kuala Terengganu, Terengganu, Malaysia. Terengganu is one of the states located at the East Coast of the Malay Peninsula, adjacent to the state of Kelantan in its southern part and Pahang state in the south. Terengganu is surrounded by seas and has a large stretch of coconut trees around the coast. The strategic location of Terengganu is located at $500 \mathrm{~km}$ northeast of Kuala Lumpur and facing the South China Sea.

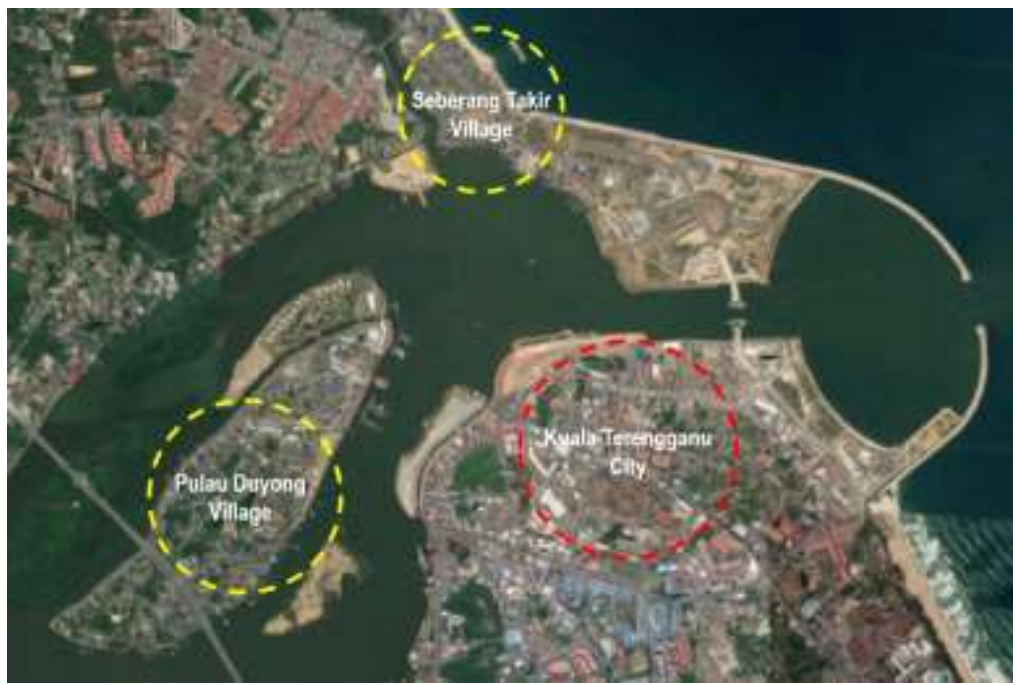

Fig. 1: Maps of the traditional settlement identified in this study

(Source: Google maps, 2018)

\subsection{Seberang Takir Village}

Seberang takir is a fisherman village located next to the suburb of Kuala Terengganu separated by a river and estuary. The main occupation of the villagers consists of fishing, fish processing and government employment. The village is divided into three focused areas namely the fishery area called Hujung Tanjung, Pengkalan Ttitian and the settlement in coastal areas in the northeast. Besides fishermen, most people are involved in small businesses such as selling fish or shrimp crackers, processing salted fish, batik printing and cottage industries. However, nowadays, this village is growing rapidly with comprehensive progress. The ongoing project aims to strengthen and promote Kuala Terengganu as 'Tourism Gateway' (ECER 2010). The project is implemented by the federal government in collaboration with the state government through the Council of the East Coast Economic Region (ECER).

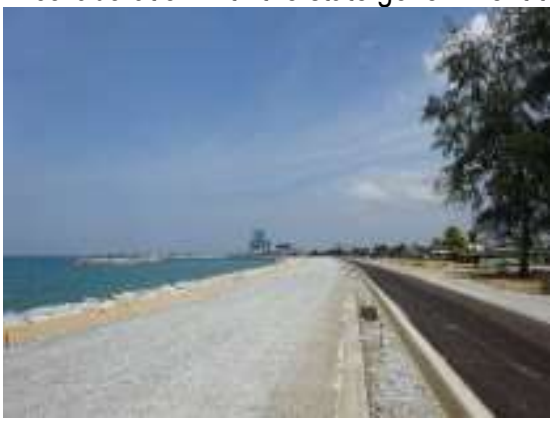

(a)

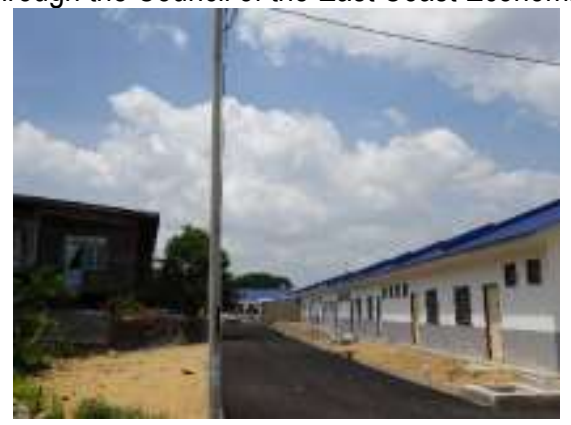

(b)

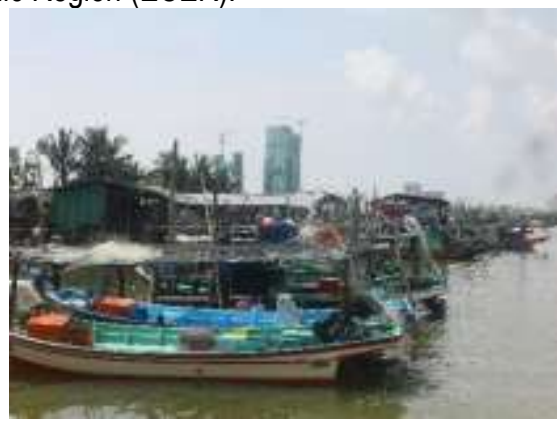

(c)

Fig. 2. (a) The construction of new roads linking the Kuala Terengganu City Center (KTCC) in Seberang Takir to Sultan Mahmud Airport (LTSM) via the coast road; (b) The construction of modern terrace house was completed; (c) The fishermen's jetty

(Source: Author) 


\subsection{Pulau Duyong Village}

Pulau Duyong village is an island which is located at the Terengganu River and is accessible by road or by boat. This village is well known for its boat-making heritage. Local people of this village still maintain the Malay culture and way of life with over $40 \%$ of the population comprising fishermen. It consists of five areas namely Duyong Sekolah, Duyong Wan Su, Duyong Kecil, Kelab Ayer and Pulau Ketam. Apart from fishermen, residents of Kampung Pulau Duyung also worked as miners' boat drivers, small businesses and government employment. A second longest bridge in Malaysia has been built across the island that connecting two of Terengganu river bank. Nowadays, the new development such as Projek Perumahan Rumah Pangsa Mampu Milik and construction of Felda headquarters, and also the remains of International Monsoon Cup sailing sports effect the cultural landscape of Pulau Duyong.

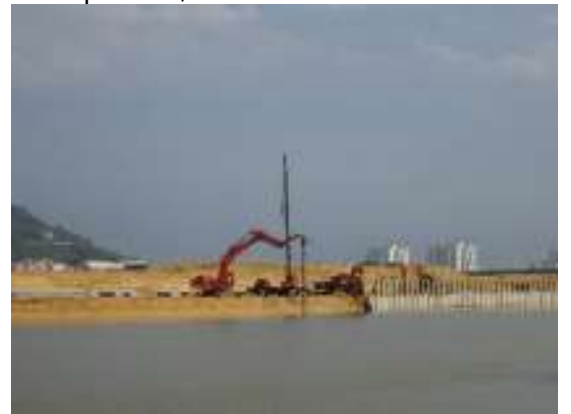

(a)

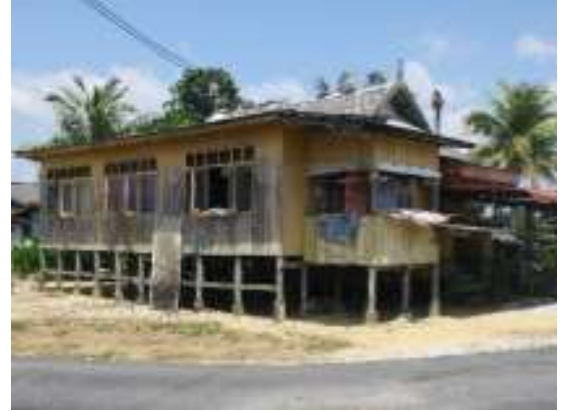

(b)

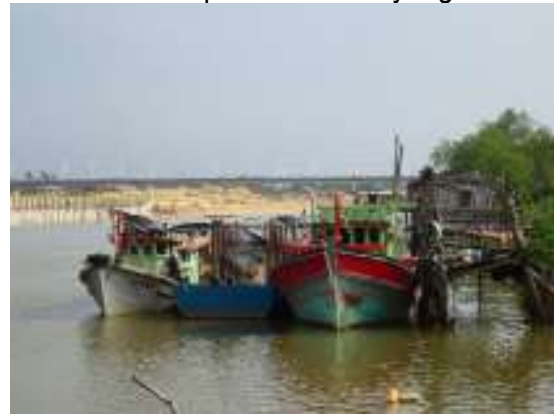

(c)

Fig. 3. (a) New development is under construction; (b) A village house characterized by Terengganu Architecture; (c) The fishermen's jetty. (Source: Author)

The main reason why Seberang Takir Village and Pulau Duyong Village are selected for this study as both villages have similarities in terms of traditional Malay cultural characteristics and values, however, new developments have taken place in both villages affecting the village identity. In general, the presence of traditional villages around the city of Kuala Terengganu conveys the socio-cultural identities of genuine Malay communities through the relationship between the choice of location of settlements, architectural design, the layout setting, climate and its surrounding. Like many other traditional settlements, both villages provide the legitimacy of Malay heritage values. The arrangement of houses built in groups or nucleated pattern. The land they live in belongs to them or family member and the house layout has no extensive boundaries. The arrangement of settlement is unplanned (informal) and open spaces exist as if designed to ensure no barrier between the boundaries of the land. These spaces can be considered or become community spaces for people's activities such as gotong royong (mutual assistance), wedding ceremony, cultural events and traditional sports.

\subsection{Findings and Discussion}

\subsection{Changes of physical attributes in the traditional Malay settlement}

The findings that represented within the scope of the study include the observations and questionnaire survey results, the results obtained have helped to get a clear picture of the current conditions on the traditional Malay settlement in Seberang Takir and Pulau Duyong villages. It also highlights several ancillary impacts that tend to influence the changes in the preservation of the traditional Malay settlement. A set of items formulated into four dimensions of physical attributes contributed to the rural liveability in traditional settlement; accessibility, safety, pleasurability and place identity. These attributes have been defined by previous scholars as follows: Accessibility includes the pattern, quantity, quality, variety and continuity of activities present, together with the connectivity between the uses (Black, C., Collins, A., \& Snell, M., 2001). Safety refers to whether a person feels safe from the risks of crime (Berrigan, D., \& Troiano, R. P, 2002). Pleasurability, as noted by Alfonzo, M. A, (2005) signifies to the level of enjoyment feeling that a setting provides with respect for a good community. While, place identity refers to the quality of an individual's relationships with a place (Najafi, 2011). Then, attributes identification will be the variables of the observation checklist.

Table 2: The inventory data on the changes of physical attributes

\begin{tabular}{|l|l|l|}
\hline Physical Attributes & \multicolumn{3}{|c|}{$\begin{array}{l}\text { Seberang Takir } \\
\text { Village (STV) }\end{array}$} & $\begin{array}{l}\text { Pulau Duyong } \\
\text { Village (PDV) }\end{array}$ \\
\hline Accessibility & & \\
\hline Clear entrance and exit & \\
\hline Near distance to destination & \\
\hline Many alternatives routes for getting from place to place & \\
\hline Lots of seating & \\
\hline Organic pattern streets & \\
\hline Safety & \\
\hline Opportunities for activities day and night & \\
\hline House located near to one another & \\
\hline House are located close to the street & \\
\hline Availability of spaces for community interaction & \\
\hline
\end{tabular}




\begin{tabular}{|l|l|}
\hline Safety back-lane & \\
\hline Safety against social problem \\
\hline Pleasurability \\
\hline Open spaces \\
\hline Expressive aesthetic \\
\hline Natural environment (hill, river, sea) \\
\hline Place Identity \\
\hline Availability of traditional house and building \\
\hline Traditional event \\
\hline Traditional socio-economic activities \\
\hline \multicolumn{1}{|c|}{ Strong Weak } \\
\hline
\end{tabular}

The data gathered through the field observation related to changes in the preservation efforts of the traditional Malay settlement regarding physical attributes are being recorded and divided into two according to the village involved which are Seberang Takir village and Pulau Duyong village to encounter the differences and similarities as shown in Table 2. From the data inventory above, it clearly shows that the availability of entrance and exit of both villages are strongly preserved and enhanced to ease the movement of reaching good and services. The connections of streets give people a maximum choice to freely make their journeys as many alternatives routes provided for getting from place to place. However, the allocation of facilities at STV is unfriendly and slightly far from the settlement area because the main road located at the centre of the village which leads to the density of traffic. Meanwhile, the main road in PDV surround the settlement area and creates the hierarchy of routes which ease the vehicular movement. Other than that, the new development at STV are mostly contributing to the vast changes of settlement and streets pattern where there is a shift of land use to a plot of new housing development and negatively affected the original traditional settlement setting. Lots of social spaces in both villages such as warung (stall), jetty, wakaf (gazebo) or pangkin (seating) are the platform to foster the social interaction. From the observation on the culture of Malays, it is identified that the culture of Malay people influencing landscape environment. The occurrence of social space is influence thought and behaviour of the Malays. The Malay communities appreciate their environmental setting as well as it is eliciting the emotional growth and experience that influences their response. The culture of Malays is evident in the landscape through their religion, belief, norms, custom and behaviour as a way of life.

Hence, in the context of safety, it was observed during night day that STV was not well lit at night and facing the risks of social problems. The questions asked: "how safe do you feel to do any outdoor activities at night?", the responded included, "safe," "slightly unsafe," and "unsafe because of a lot of drug addict." The data discovered women responded to their neighbourhoods as insecure at night. In contrary, PDV shows the positive response towards safety during day and night-time, however, the availability of social problems and crime have still existed in a lower number. Staying in a neighbourhood that is considered unsafe at night is an obstruction to regular social activity among society, especially women and teenagers. The unsafe environment will affect the feeling of doing activities outside the home. These factors may border the successfulness of social interaction. Also, the allocation of house setting plays a vital role in determining the safety of the neighbourhood. Houses located near one another and are close to the street can serve to lower the risks of crime as the people can be seen on the roads

According to the observation data, both villages was lack of green open spaces near settlement area. As open spaces have an important in neighbourhood life in fostering social interactions that is elemental for social cohesion and encourage a sense of community. Without open green spaces, the temperature increases and impact on environmental damage. While, the reclamation land along the river of STV and a part of PDV give the adverse effects which increase the noise pollution through the existence of main road and activities along the river, as well as lead to the deterioration of the cultural heritage value, decreases the visual quality and the destruction of the environment. Even though, the new development along the river allows social welfare to enhanced through providing the facilities and infrastructure and have the potential to be a public recreation space and mixed development, nevertheless, the transformation of the heritage environment through redevelopment is believed to have resulted in the deterioration of the image quality, biodiversity and ecosystem stability.

Furthermore, the architectural of Terengganu traditional houses have their own identity and design. The diversity in types of dwellings reflects the history of the people and the local wisdom. For example, the main styles of Terengganu architecture are Rumah Bujang Berpeleh and Rumah Limas Belanda or known as Rumah Limas Bungkus, the differences types of houses can recognise through the variations of the cross-roof. The vernacular architecture is symbolic to the Malay heritage and local wisdom. It has produced by an organic material, sustainable concept and provided the ability to adapt to the climate condition. Thus, the observation discovered that PDV had solid physical attributes of traditional Malay settlement concept which still preserved until today. However, the traditional socioeconomic was gradually changes due to many factors such as the growth of rapid industrialisation, lack of understanding towards the Malay cultural heritage and limited of workspaces.

\subsection{Demographic result}

Tables provided in each section reports the result from the questionnaire survey conducted in Seberang Takir Village (STV) and Pulau Duyong Village (PDV). A total of 220 respondents have participated in this study. Seberang Takir Village has placed by bigger size of respondents (120) with Pulau Duyong Village was slightly lower of 100 respondents. Majority of the respondent's age between 18-60 years old with almost fair distribution among gender. Respondents were consisted of 72 males (60\%) and 48 females (40\%) in STV, 
while 61 males (61\%) and 39 females (39\%) in PDV. Male was more interested to answer the survey compared to female. Group of age of adults made $75(62 \%)$ in STV, and $56(56 \%)$ in PDV from the total population. More than $60 \%$ of the participants, majority of whom are male adults and elderly, have been residing in the village for twenty years.

Table 3: Socio-demographic of the residents

\begin{tabular}{|c|c|c|c|c|c|c|c|}
\hline \multirow{3}{*}{ Demographics } & \multirow{3}{*}{ Group } & & & & & \multirow{3}{*}{$\begin{array}{l}\text { STV } \\
n=120\end{array}$} & \multirow{3}{*}{$\begin{array}{l}\text { PDV } \\
n=100\end{array}$} \\
\hline & & STV & PDV & STV & PDV & & \\
\hline & & \multicolumn{2}{|c|}{ Frequency } & \multicolumn{2}{|c|}{ Percentage $\%$} & & \\
\hline Sex & $\begin{array}{l}M \\
F\end{array}$ & $\begin{array}{l}72 \\
48\end{array}$ & $\begin{array}{l}61 \\
39\end{array}$ & $\begin{array}{l}60 \% \\
40 \%\end{array}$ & $\begin{array}{l}61 \% \\
39 \%\end{array}$ & 120 & 100 \\
\hline Age & $\begin{array}{l}\text { Teenagers } \\
\text { Adult } \\
\text { Elderly }\end{array}$ & $\begin{array}{l}31 \\
75 \\
14\end{array}$ & $\begin{array}{l}21 \\
56 \\
23\end{array}$ & $\begin{array}{l}26 \% \\
62 \% \\
12 \%\end{array}$ & $\begin{array}{l}21 \% \\
56 \% \\
23 \%\end{array}$ & 120 & 100 \\
\hline Length of residence & $\begin{array}{l}\text { Less than } 5 \text { years } \\
5-10 \\
11-15 \\
15-20 \\
\text { More than } 20 \text { years }\end{array}$ & $\begin{array}{l}15 \\
10 \\
6 \\
26 \\
63\end{array}$ & $\begin{array}{l}10 \\
5 \\
11 \\
13 \\
61\end{array}$ & $\begin{array}{l}12 \% \\
8 \% \\
5 \% \\
22 \% \\
53 \%\end{array}$ & $\begin{array}{l}10 \% \\
5 \% \\
11 \% \\
13 \% \\
61 \%\end{array}$ & 120 & 100 \\
\hline
\end{tabular}

5.3 Factors contributes to the impacts of changes on the traditional Malay settlement

The factors have identified contributed to the changes in the traditional Malay settlement as presented below in Table 4.

Table 4: The questionnaire survey data on the factors of changes in the traditional Malay settlement

\begin{tabular}{|c|c|c|c|c|c|c|c|c|c|c|c|c|}
\hline \multirow{3}{*}{$\begin{array}{l}\text { Factors of changes in the traditional } \\
\text { Malay settlement }\end{array}$} & \multicolumn{6}{|c|}{ Seberang Takir Village (STV) } & \multicolumn{6}{|c|}{ Pulau Duyong Village (PDV) } \\
\hline & \multicolumn{2}{|c|}{ Agree } & \multicolumn{2}{|c|}{ Uncertain } & \multicolumn{2}{|c|}{ Disagree } & \multicolumn{2}{|c|}{ Agree } & \multicolumn{2}{|c|}{ Uncertain } & \multicolumn{2}{|c|}{ Disagree } \\
\hline & $\mathbf{F}$ & $\%$ & $\mathbf{F}$ & $\%$ & $\mathbf{F}$ & $\%$ & $\mathrm{~F}$ & $\%$ & $\mathbf{F}$ & $\%$ & $\mathbf{F}$ & $\%$ \\
\hline Surveys & & & & & & $n=120$ & & & & & & $n=100$ \\
\hline Natural disaster & 52 & $43 \%$ & 35 & $29 \%$ & 33 & $28 \%$ & 70 & $70 \%$ & 17 & $17 \%$ & 13 & $13 \%$ \\
\hline Lack of maintenance & 69 & $57 \%$ & 31 & $26 \%$ & 20 & $17 \%$ & 71 & $71 \%$ & 21 & $21 \%$ & 8 & $8 \%$ \\
\hline Modern development & 93 & $78 \%$ & 27 & $22 \%$ & 0 & $0 \%$ & 87 & $87 \%$ & 13 & $13 \%$ & 0 & $0 \%$ \\
\hline $\begin{array}{l}\text { Destruction by irresponsible parties and } \\
\text { individuals }\end{array}$ & 78 & $65 \%$ & 26 & $22 \%$ & 16 & $13 \%$ & 62 & $62 \%$ & 24 & $24 \%$ & 14 & $14 \%$ \\
\hline $\begin{array}{l}\text { Lack of awareness and understanding on } \\
\text { the function of cultural heritage }\end{array}$ & 87 & $73 \%$ & 18 & $15 \%$ & 15 & $12 \%$ & 60 & $60 \%$ & 29 & $29 \%$ & 11 & $11 \%$ \\
\hline Traditional product declining in the market & 62 & $52 \%$ & 31 & $26 \%$ & 27 & $22 \%$ & 71 & $71 \%$ & 26 & $26 \%$ & 3 & $3 \%$ \\
\hline
\end{tabular}

The survey result shows that the main factors of changes were the natural disaster, lack of maintenance, modern development, destruction by irresponsible parties and individuals, lack of awareness and understanding on the function of cultural heritage and the declining of traditional product in the market. All factors mentioned were strongly related to the impacts of the changes of the traditional Malay settlement. The percentage of respondents agreeing on the impact of modern development is notably the highest for both villages: STV (93\%) and PDV (87\%) with $0 \%$ in disagreeing choice. On the other hand, the lowest percentages of agreement were noted in regard to the impact of natural disaster and lack of awareness (STV $=43 \%$, PDV $=60 \%$ ). The respondents in STV also agreed that lack of awareness and understanding of the function of cultural heritage contributed to the change (73\%), although some were "uncertain" $(15 \%)$, and some "disagreed" (12\%). While lack of maintenance and declining traditional product in the market has the same score of agree with $71 \%$ in PDV as a second highest percentage. The answer was received from who are residing the village more than 20 years.

According to the results, the geographical factors of lowlands is usually affected flooding and beach erosion due to the phenomenon of massive tide and heavy rain. The beach and nearby villages will be flooded by shallow seawater during the early monsoon season. Thus, the land reclamation process at STV and PDV acts as reclaiming the beach from erosion. Also, along the seas of STV, the protective rock wall was installed to buffer strong waves. It has agreed that natural disaster is massively affecting the original setting of traditional settlement. However, the choice of disagree received the highest percentages (28\%) in STV comes from who residing the village less than 15 years. Furthermore, lack of maintenance by local authority also one of the factors lead to the changes of the traditional settlement. The lack of maintenance has happened since limited funding availability and difficult in seeking supports regarding maintenance and management process. As recorded by the questionnaire data, no specific maintenance or management schedule is being done from the local authority although they initiated the preservation efforts. This situation may financially burden the owner because heritage preservation is one of the challenges as it requires high technical expertise and a relentless effort. This study suggests on the efforts regarding maintenance and managements, regularly or adequately scheduled of the program with low budgets can be implemented by the initiatives of any parties to avoid financial burdens of individuals. 
The traditional Malay settlement also has changed due to abandoning, demolition, an introduction of new materials and replacement with new standards of housing. Also, the traditional Malay lifestyle and the kampong living setting sphere began replacing by what's known as the more 'westernised' looked housing scheme. It has resulted in the start of replacing and demolishing the originality of the traditional Malay settlement characteristics. This threat has linked to the other threats found include modernisation, industrialisation, globalisation and migration. The massive amount of migration from rural to urban areas which are leading to the abandon and loss of the traditional Malay settlement. Destruction by irresponsible parties and individuals and lack of awareness and understanding of the function of cultural heritage lead to the destruction of traditional settlement identity. An approximately similar pattern indicated by respondents in STV where received "agree" (65\%), "uncertain" (22\%) and "disagree" (13\%), while in PDV received "agree' (62\%), "uncertain" (24\%) and "disagree" (14\%). The "uncertain" answer obtained from who are living in the village less than 20 years. Awareness in the context of conservation refers to the sense of respect and appreciation of inheritance assets. Lack of awareness on the function of cultural heritage among the society will be decreasing the sense of belonging or community's sensitivity towards to the environment. The fewer practices of traditional Malay lifestyle would have resulted in being lack of knowledge of the Malay culture and tradition at the same time losing their identity. Lastly, the traditional products are declining in the market because insufficient of the basic structure and the issues of unwilling to inherit the traditional works among teenagers. Thus, these all factors discussed above have led to the vulnerability of heritage values.

\subsection{Conclusion and recommendation}

In conclusion, the socio-demographic profiles of the respondents have influenced how they viewed the factors causing the changes in their traditional settlements. Almost all the "agree" answer received by the residents who live in these village more than 20 years. It is indicated that the more longer the population residing in their village, the more higher awareness and knowledge towards their settlement. Furthermore, the teenagers are tending to answer 'uncertain' which indicate them lack sensitivity towards their surroundings. Thus, this study concern on the preservation efforts of the traditional Malay settlement by recommending some approaches; first, the Malay vernacular architectures should be gazetted for preservation efforts and as part of cultural heritage tourism and any changes made supposed to protect the uniqueness of the village despite new developments. Secondly, provide more activities and incentives program related to the traditional village and cultural heritage to increase their awareness about their surrounding or the environmental condition as affected by the urbanisation. Among the measures that can be made is exposure through electronic media or print media, such as campaigns, reality show related heritage, forums, competitions and so on. Lastly, the roles of ancestors, parents, relatives and community in particular aspects are essential to promote the continuity of knowledge that must be maintained for Malay culture to survive as knowledge is a passed from one generation to another. Thus, these actions would allow a better understanding of the function of intangible and tangible cultural heritage. As a result, the more traditional settlements will establish and preserved in all aspects; environmental, social and economic.

\section{Acknowledgements}

The authors would like to thank The National University of Malaysia, Institute of Malay World and Civilization to conduct this study. This Research was funded by Grant DCP-2017-008/3.

\section{References}

Abd. Razak, D (2015). Save our vanishing kampong, The New Straits Times, 24 December 2015

Ahmad, R. (2013). Cultural landscapes as heritage in Malaysia: Potentials, threats, and current practices. Utrecht University.

Alfonzo, M. A. (2005). To walk or not to walk? The hierarchy of walking needs. Environment and behavior, 37(6), 808-836.

Ariffin, N. F. M. (2007). Role of Cultural Landscape in Improving the Identify of the Kuala Terengganu Town Centre as a Malay Historic Town (Doctoral dissertation, Universiti Teknologi Malaysia).

Berita Harian (2016, 3 Julai). 29 kampung tradisi di Pulau Pinang bakal lenyap.

Berrigan, D., \& Troiano, R. P. (2002). The association between urban form and physical activity in US adults. American journal of preventive medicine, 23(2), 74-79.

Black, C., Collins, A., \& Snell, M. (2001). Encouraging walking: the case of journey-to-school trips in compact urban areas. Urban studies, 38(7), $1121-1141$.

ECER (2010). Kuala Terengganu City Centre: A Vibrant Heritage Waterfront City. East Coast Economic Region Development Council (ECERDC).

Ghoomi, H. A., Yazdanfar, S. A., Hosseini, S. B., \& Maleki, S. N. (2015). Comparing the components of sense of place in the traditional and modern residential neighborhoods. Procedia-Social and Behavioral Sciences, 201, 275-285.

Jani, H. H. M., \& Hussain, M. R. M. (2014). Reclaiming the loss of the Minangkabau cultural landscape in Negeri Sembilan. Procedia-Social and Behavioral Sciences, $153,317-329$.

Jani, M., Hanurhaza, H., Hussain, M., \& Ramzi, M. (2011). Cultural landscape: a new paradigm for landscape architecture. 
Lai, L. Y., Said, I., \& Kubota, A. (2013). The roles of cultural spaces in Malaysia's historic towns: The case of Kuala Dungun and Taiping. Procedia-Social and Behavioral Sciences, 85, 602-625.

McGranahan, G., \& Satterthwaite, D. (2014). Urbanisation: Concepts and Trends. London: IIED

McGregor, J. A., Camfield, L., Masae, A., \& Promphaking, B. (2008). Wellbeing, development and social change in Thailand. Thammasat Economic Journal, $26(2), 1-27$.

Najafi, M., \& Shariff, M. K. B. M. (2011). The concept of place and sense of place in architectural studies. International Journal of Human and Social Sciences, 6(3), 187193

Nguyen, H. M. (2013). Cultural Behavior: Climatic adaptive approaches of traditional housing in Vietnam Northern lowland area. Procedia-Social and Behavioral Sciences, $85,368-382$

Radzuan, M., \& Syahrul, I. (2016). Cultural heritage incentives for the conservation of traditional settlements: the case of Malaysia, Japan and South Korea/Indera Syahrul Mat Radzuan (Doctoral dissertation, University of Malaya).

Samsudin, N. A (2017). Pembangunan Semula Tebingan Sungai Dan Impak Terhadap Rupabandar Bandaraya Kuala Terengganu. Persidangan Geografi Dan Alam Sekitar Kali Ke-6

Samsudin, P. Y., \& Maliki, N. Z. (2015). Preserving cultural landscape in homestay programme towards sustainable tourism: brief critical review concept. Procedia-Social and Behavioral Sciences, 170, 433-441.

Shuhana, S. (2011). Townscape Revisited: Unravelling the Character of the Historic Townscape in Malaysia. Kuala Lumpur: Universiti Teknologi Malaysia Press. 